International Journal of Engineering \& Technology, $9(2)(2020) 560-567$
International Journal of Engineering \& Technology
SPC
Website: www.sciencepubco.com/index.php/IJET
Research paper

\title{
Improvement of cost performance accompanied by quality control using value engineering and six sigma methods in high-rise building project
}

\author{
Khairul Rochman ${ }^{1 *}$, Budi Susetyo ${ }^{1}$ \\ ${ }^{1}$ Civil Engineering Department, Mercu Buana University, Jakarta, Indonesia \\ *Corresponding author E-mail: khairulrhmn9@gmail.com
}

\begin{abstract}
Construction projects are unique, complex, and have high risks, thereby increasing priorities. The application of the concept of mega construction with the risk of increasing costs needs to be eliminated by the value engineering and quality control methods. Re-analyzing a development plan is an option to save costs, but still in accordance with applicable specifications and conditions. Quality control with the six sigma method can be defined as relating to systemic and systematic to identify and eliminate waste or activities that are not added activities that do not add value, radical continuous improvement to achieve six sigma performance levels, by flowing products (material, work-inprocess, output) and information using a Pull system from internal and external users to achieve goals and perfection with only produce a small amount for every one million opportunity or operation. The results of the case study conducted on the upper structure work (column and beam) based on the design value of the multi-storey building obtained a cost efficiency of $9.27 \%$ and $3.19 \%$ of the initial cost design. Whereas the implementation of six sigma is used to reduce work defects from excessive targets and low worker skills. NCR from this highrise building project, obtained a value of 39 defects, with a Disability Per Million Opportunity value of 3.125 DPMO, which after being converted to a sigma table, is included in the 4.23 sigma category and a DMAIC (Define-Measure-Analyze-Improve-Control) in order to maintain quality and reduce defects resulting from upper structure work.
\end{abstract}

Keywords: Value Engineering; Six Sigma; Upper Structure Work; High-Rise Building.

\section{Introduction}

Along with the development of construction in Indonesia, infrastructure facilities in the world of civil engineering also experienced quite rapid development, as seen in 2018, there were 64 percent of civil projects compared to building construction projects (36\%). Although still colored by developments in the civil sector, this sector appears to provide figures with a value of 267,146 trillion in 2019 [1]. This has resulted in increasingly competitive service providers, in providing the best service to project owners. With careful planning, design that meets the requirements, and good construction management will get quality, architectural, efficient, and optimal construction [2]. On the other hand, the construction of construction projects is unique, complex, has a high risk so that many factors can result in increased costs. The larger the project, the more complex the mechanism means the more problems that must be faced. If not handled properly, these problems can result in increased costs, quality deviations, waste of resources, and failure to achieve desired goals and objectives [3]-[4]. Dominant factors affecting cost overruns are group management factors, project financial factors and resource factors. One of the problems that arise in the implementation of building construction is the increase in cost or excess cost of the total project cost ranging from 5\% $7 \%$ due to variations in orders [5]-[7]. While the results of research waste in construction: over ordering or under ordering due to mistakes in quantity surveys, selection of low quality products, design and construction detail errors, supplying materials in loose form and poor resource management. [8]-[10].

\section{Page layout}

Compilation of research data organized into three categories as research variables, namely data about the needs of the work of the upper structure, data on the application of value engineering and data on the application of six-sigma. Data Effectiveness of Structure Work. The value engineering application data is the evaluation of the initial design and use of materials based on the evaluation phase, information phase, function analysis phase, creativity phase, evaluation phase (function and cost), presentation phase and development phase [11]-[14]. Six-sigma implementation data, published evaluation of material use with DMAIC (Define, Measure, Analyze, Improve, Control) [15][18]. A schematic overview of data type compilation is shown in Figure 1. 


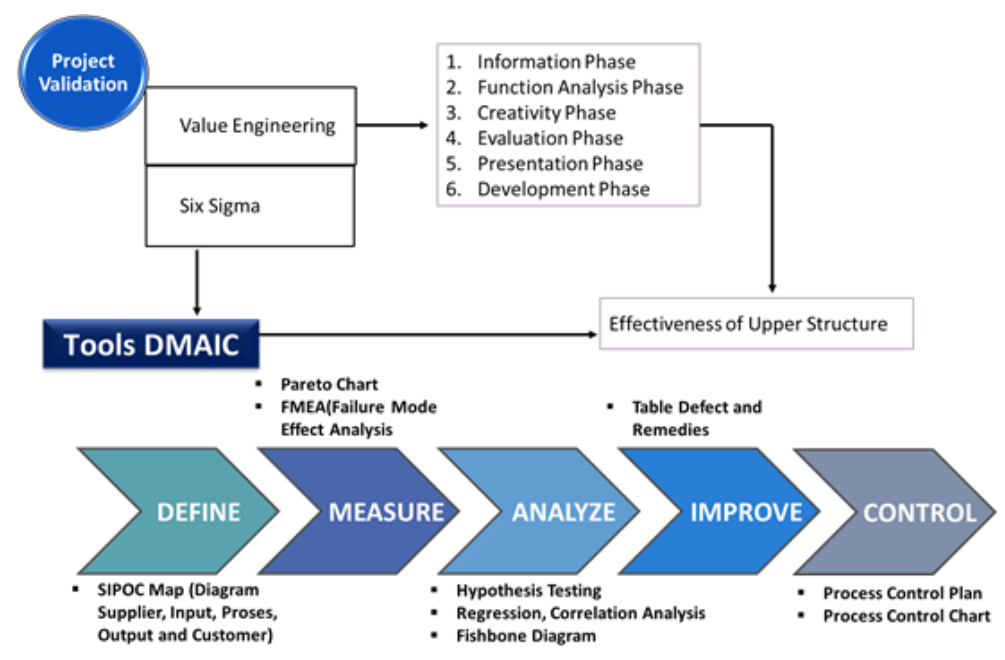

Fig. 1: Data Compilation.

\section{Result and discussion}

\subsection{Project validation based on value engineering}

1) Information Phase

In this case study discussed about the implementation of value engineering studies, where researchers take the object of research in the construction of academic buildings (workshops \& labotratory FTUI).

a) Initial cost model

Scope of work on the construction project of the FTUI Integrated Teaching Laboratory \& Workshop Building. The budget plan is made by Owner Estimate (self-estimated price) made by the tender committee assisted by a construction management consultant with the following details:

Table 1: Cost Budget Plan Recapitulation

\begin{tabular}{llll}
\hline No & Work Item & Total Cost & Weight $(\%)$ \\
\hline 1 & Preliminaries & $2.488 .610 .606,87$ & $4,52 \%$ \\
2 & Structure & 16.398 .093 .027 .40 & $29,78 \%$ \\
3 & Architecture & $14.127 .618 .080,09$ & $25,66 \%$ \\
4 & MEP & $22.041 .031 .207,50$ & $40,04 \%$ \\
Total & & $55.055 .352 .921,86$ & $100,00 \%$ \\
Total + Ppn $10 \%$ & $60.560 .888 .214,04$ & \\
\hline
\end{tabular}

\begin{tabular}{llll} 
& Table 2: Cost Breakdown Structure & Total Cost & \\
\hline No & Work Item & $2.989 .140 .000,00$ & Weight $(\%)$ \\
\hline 1 & Foundation Structure & $10.555 .360 .554,84$ & $18,23 \%$ \\
2 & Upper Structure & $812.604 .105,16$ & $64,37 \%$ \\
3 & Steel Column & $203.396 .880,60$ & $4,96 \%$ \\
4 & $2^{\text {nd }}$ Floor Steel Structure & $142.266 .045,40$ & $1.24 \%$ \\
5 & Steel Structure of Mezzanine & $538.555 .087,55$ & $0.87 \%$ \\
6 & Roofing Steel Structure & $1.156 .770 .353,83$ & $3.28 \%$ \\
7 & Supporting Buildings \& Infrastructure & $16.398 .093 .027,40$ & $7,05 \%$ \\
Total & & & $100,00 \%$ \\
\hline
\end{tabular}

b) Pareto Distribution Analysis

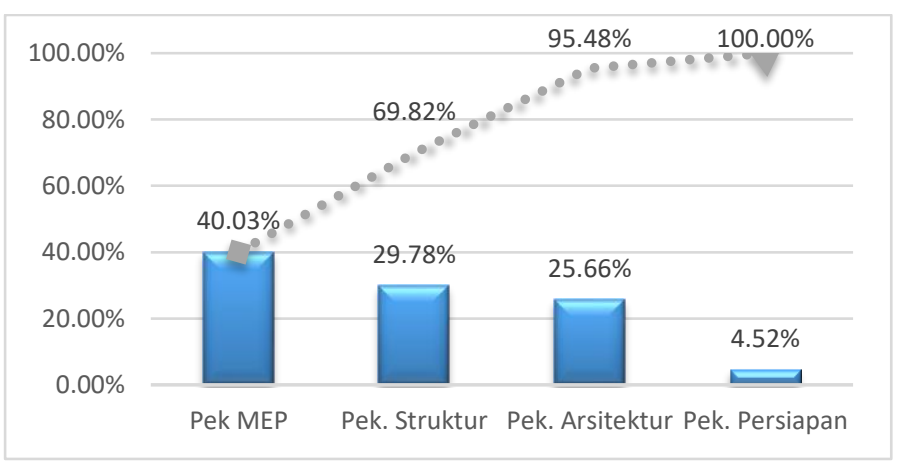

Fig. 2: Pareto Diagram Result.

From the above data the cost of MEP work does have the highest cost, but based on there have been several previous studies that have done value engineering on this work, the authors try to make an alternative scope for the structure work, it needs to be devoted to the subdivision of the structural work what can be done is the application of value engineering including upper structure work.

2) Function analysis phase 
At the function analysis stage, the first activity carried out is to identify functions randomly and then group them together, and identify each type of function.

Table 3: Analysis of Functions in Column Work

\begin{tabular}{lllll}
\hline No. & Component & Verb & Noun & Function \\
\hline 1 & Concrete & Distribute & Load & Primary \\
2 & Iron & Distribute & Load & Primary \\
3 & Formwork & Printing & Column & Secondary \\
\hline
\end{tabular}

Table Error! No text of specified style in document.. Analysis of Functions in Beam Work

\begin{tabular}{lllll}
\hline No. & Component & Verb & Noun & Function \\
\hline 1 & Concrete & Hold & Load & Primary \\
2 & Iron & Hold & Load & Primary \\
3 & Formwork & Printing & Beam & Secondary \\
\hline
\end{tabular}

Then the functions of the structure work items are arranged in a FAST diagram.

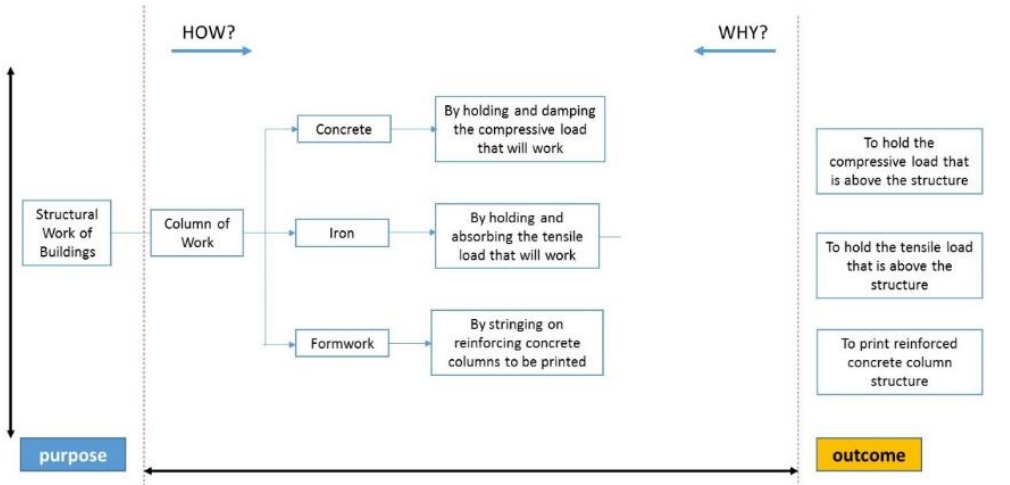

Fig. 3: FAST Diagram of Column Work.

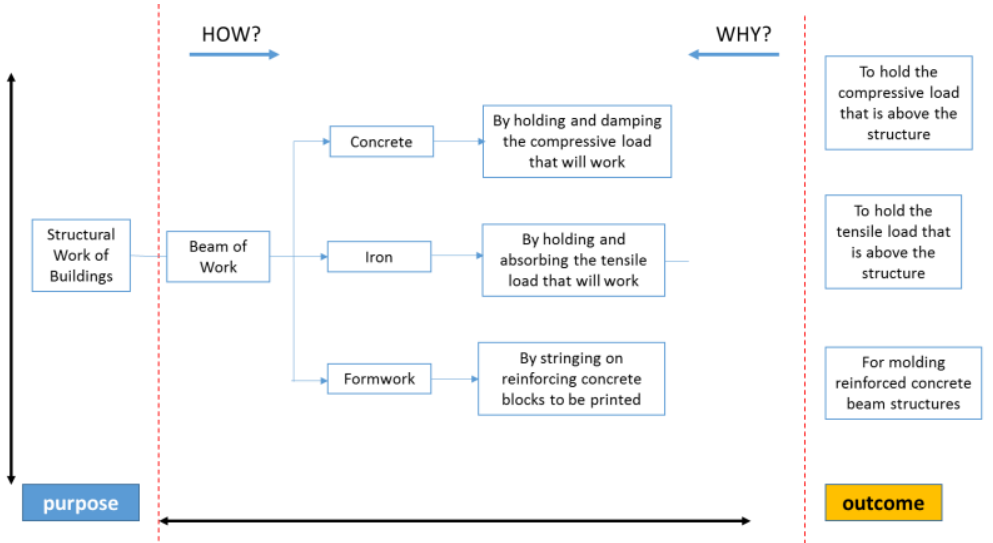

Fig. 4: FAST Diagram of Beam Work.

Table 5: Cost to Worth Recapitulation of Upper Structure Analysis Work

\begin{tabular}{llllll}
\hline No. & Uraian & Cost & Worth & C/W Indeks & Information \\
\hline 1 & Column & $2.134 .027 .453,09$ & 1.895 .698 .472 & 1,12 & Reduce $2,26 \%$ \\
2 & Beam & 2.662 .631 .214 .84 & $2.357 .604 .615,4$ & 1,13 & Reduce 2,89\% \\
\hline
\end{tabular}

3) Creativity Phase

Alternatives to high-cost work items will be sought, which will then be selected to find the best alternative at the analysis stage.

Table 6: Alternative Substitute for Column Work

\begin{tabular}{l}
\hline Alternative substitute for column work \\
Item: Column Structure B = Function primary/Basic \\
Function: Withstand the Load S = Function Secondary \\
\begin{tabular}{ll} 
No & Alternative \\
1 & Improve concrete quality from K350 to K400 to reduce dimensions \\
\hline
\end{tabular}
\end{tabular}

Table 7: Alternative Substitute for Beam Work

\begin{tabular}{l} 
Alternative substitute for beam work \\
Item: Beam Structure B = Function primary/Basic \\
Function: Withstand the Load S = Function Secondary \\
$\begin{array}{ll}\text { No } & \text { Alternative } \\
1 & \text { Improve concrete quality from K350 to K400 to reduce dimensions }\end{array}$ \\
\hline
\end{tabular}

Following modeling of alternative structures with the Etabs program represents the design of the original building. 
Table 8: Alternative Design Column and Beams

\begin{tabular}{|c|c|c|c|c|c|c|c|c|}
\hline $\begin{array}{l}\text { Descrip- } \\
\text { tion }\end{array}$ & $\begin{array}{l}\text { Project Technical } \\
\text { Data }\end{array}$ & $\begin{array}{l}\text { Alternative De- } \\
\text { sign }\end{array}$ & Floor & Beam & Span & $\begin{array}{l}\text { To- } \\
\text { tal }\end{array}$ & $\begin{array}{l}\text { Initial dimen- } \\
\text { sions }\end{array}$ & $\begin{array}{l}\text { Alternative } \\
\text { VE }\end{array}$ \\
\hline \multirow{10}{*}{$1^{\text {st }}$ Floor 1} & Work Item & Work Item & \multirow[t]{7}{*}{ 2-Roof } & Main Beam & & & Existing & - \\
\hline & Column & Column & & Simple & & & & \\
\hline & K1 45/90 & K1 45/90 & & S1 & 1,9 & 4 & $30 / 60$ & $30 / 60$ \\
\hline & $\mathrm{K} 1 \mathrm{~A} 45 / 90$ & $\mathrm{~K} 1 \mathrm{~A} 45 / 90$ & & $\mathrm{~S} 2$ & 8 & 8 & $30 / 60$ & $30 / 60$ \\
\hline & K1B 45/90 & K1B 45/90 & & S3 & 4 & 6 & $30 / 40$ & $30 / 40$ \\
\hline & $\mathrm{K} 1 \mathrm{C} 45 / 90$ & $\mathrm{~K} 1 \mathrm{C} 45 / 90$ & & $\mathrm{~S} 4$ & 1,9 & 1 & $25 / 40$ & $25 / 40$ \\
\hline & K2 25/90 & K2 25/90 & & S5 & 4,5 & 1 & $25 / 40$ & $25 / 40$ \\
\hline & K3 40/40 & K3 40/40 & \multirow[t]{10}{*}{$2^{\text {nd }}$ Floor } & S6 & 3,5 & 1 & $25 / 40$ & $25 / 40$ \\
\hline & K4 55/90 & K4 55/90 & & S8 & 3,2 & 6 & $25 / 40$ & $25 / 40$ \\
\hline & K5 30/30 & K5 30/30 & & S9 & 2,8 & 1 & $30 / 50$ & $30 / 50$ \\
\hline \multirow{6}{*}{$2^{\text {nd }}$ Floor } & K1 45/90 & K1 40/90 & & S9A & 2,5 & 1 & $15 / 40$ & $15 / 40$ \\
\hline & K1A 45/90 & K1A 40/90 & & S10 & 3,5 & 2 & $30 / 50$ & $30 / 50$ \\
\hline & K1B 45/90 & K1B 45/90 & & S11 & 5 & 3 & $30 / 50$ & $30 / 50$ \\
\hline & $\mathrm{K} 1 \mathrm{C} 45 / 90$ & $\mathrm{~K} 1 \mathrm{C} 40 / 90$ & & $\mathrm{~S} 1$ & 1,9 & 10 & $30 / 60$ & $30 / 55$ \\
\hline & K2 25/90 & K2 25/90 & & $\mathrm{S} 2$ & 8 & 8 & $30 / 60$ & $30 / 55$ \\
\hline & K4 55/90 & K4 50/90 & & S2A & 8 & 2 & $30 / 60$ & $30 / 60$ \\
\hline \multirow{6}{*}{$\begin{array}{l}3,4,5 \\
\text { Floor }\end{array}$} & K1 40/85 & K1 40/80 & & $\mathrm{S} 3$ & 4 & 6 & $30 / 40$ & $30 / 35$ \\
\hline & K1A 40/85 & K1A 40/80 & \multirow{9}{*}{$3^{\text {rd }}$ Floor } & S4 & 1,9 & 1 & $25 / 40$ & $25 / 35$ \\
\hline & K1B 45/90 & K1B 45/90 & & S5 & 4,5 & 1 & $25 / 40$ & $25 / 35$ \\
\hline & $\mathrm{K} 1 \mathrm{C} 40 / 85$ & $\mathrm{~K} 1 \mathrm{C} 40 / 80$ & & S6 & 3,5 & 1 & $25 / 40$ & $25 / 35$ \\
\hline & K2 25/85 & K2 25/85 & & S8 & 3,2 & 6 & $25 / 40$ & $25 / 35$ \\
\hline & K4 40/85 & K4 40/80 & & S8A & 6,7 & 1 & $25 / 50$ & $25 / 50$ \\
\hline \multirow{6}{*}{$\begin{array}{l}6,7,8 \\
\text { Floor }\end{array}$} & K1 40/80 & K1 40/75 & & S9 & 2,8 & 1 & $15 / 40$ & $15 / 35$ \\
\hline & $\mathrm{K} 1 \mathrm{~A} 40 / 80$ & $\mathrm{~K} 1 \mathrm{~A} 40 / 75$ & & $\mathrm{~S} 1$ & 1,9 & 10 & $30 / 60$ & $30 / 55$ \\
\hline & K1B 40/80 & K1B 40/80 & & $\mathrm{S} 2$ & 8 & 10 & $30 / 60$ & $30 / 55$ \\
\hline & $\mathrm{K} 1 \mathrm{C} 40 / 80$ & $\mathrm{~K} 1 \mathrm{C} 40 / 75$ & & S3 & 4 & 6 & $30 / 40$ & $30 / 35$ \\
\hline & K2 25/80 & K2 25/80 & \multirow{8}{*}{$\begin{array}{l}4^{\text {th }} \text { Floor }-9^{\text {th }} \\
\text { Floor }\end{array}$} & S4 & 1,9 & 1 & $25 / 40$ & $25 / 35$ \\
\hline & $\mathrm{K} 4$ 40/80 & $\mathrm{K} 4$ 40/75 & & S5 & 4,5 & 1 & $25 / 40$ & $25 / 35$ \\
\hline \multirow{3}{*}{$9^{\text {th }}$ Floor } & K1A 40/60 & $\mathrm{K} 1 \mathrm{~A} 40 / 50$ & & S6 & 3,5 & 1 & $25 / 40$ & $25 / 35$ \\
\hline & K1B 40/60 & K1B 40/50 & & S8 & 3,2 & 6 & $25 / 40$ & $25 / 35$ \\
\hline & K2 25/60 & K2 25/60 & & S9 & 2,8 & 1 & $15 / 40$ & $15 / 35$ \\
\hline \multirow{3}{*}{$10^{\text {th }}$ Floor } & K1A 40/60 & $\mathrm{K} 1 \mathrm{~A} 40 / 50$ & & & & & & \\
\hline & K1B 40/60 & K1B 40/50 & & & & & & \\
\hline & K2 25/60 & K2 25/60 & & & & & & \\
\hline
\end{tabular}
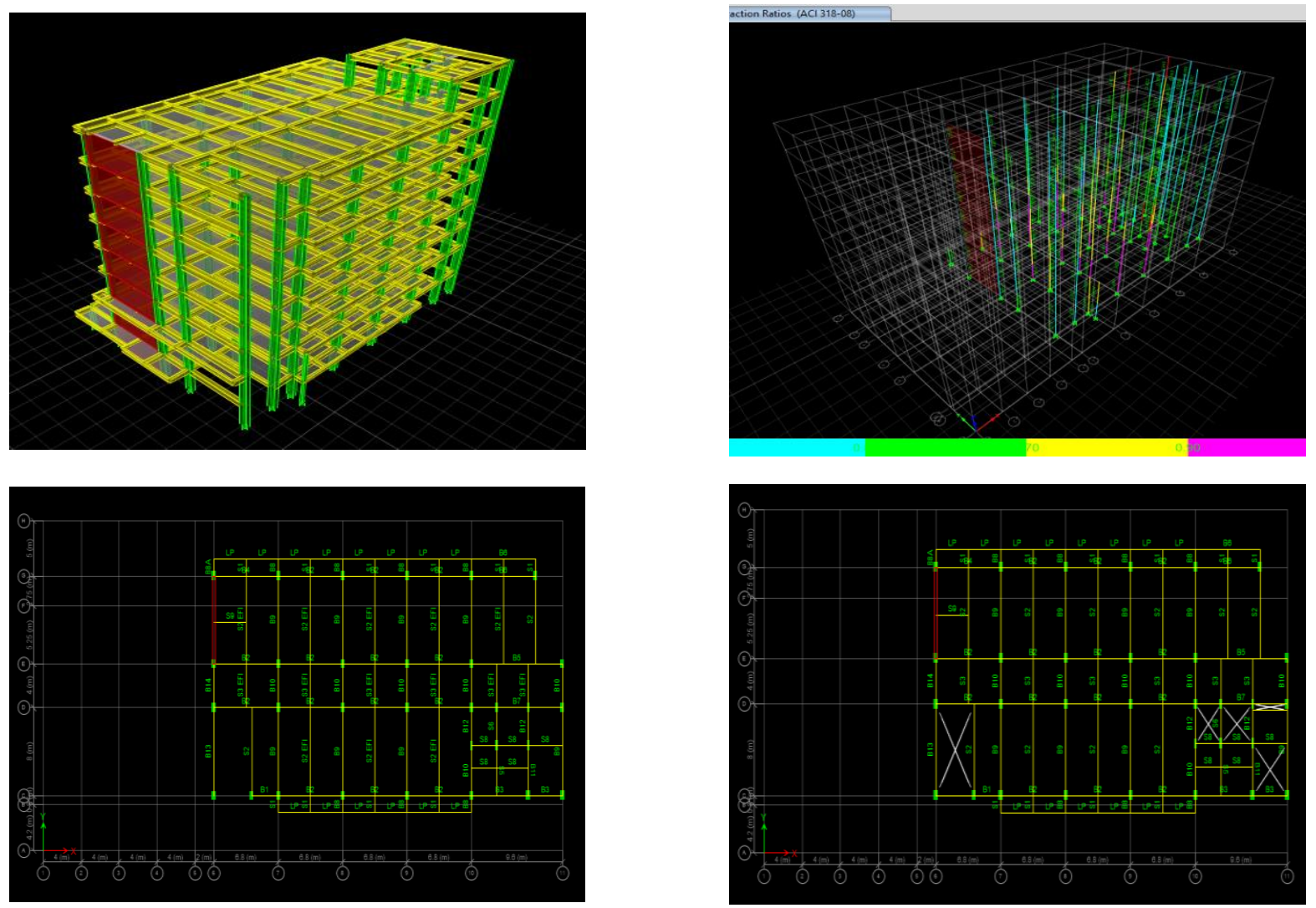

Fig. 5: Modeling Columns and Beams with the 2016 ETABS Program.

4) Evaluation Phase

In the analysis of profits and losses, ideas obtained at the creative stage are recorded their advantages and disadvantages, then weighted in value. Evaluation of ideas must be as objective as possible. 
Work Item: Column and Beam

Table 9: Analysis of Initial Design Column Loss and Beam Loss

Preliminary Design (K350 Cast In Situ Reinforced Concrete)

The advantage

The connection is more unified so it is stronger

Loss

Construction time is longer than using precast

The weather is very influential when working

(Increasing Concrete Quality)

Table 10: Analysis of Alternative Loss and Column Beam Losses

Work Item: Column and Beam

Alternative (Reinforced Concrete Cast In Situ K400)

The advantage

Loss

Because of higher quality, dimensions can be reduced making it cheaper and reducing volume

The construction time is longer

compared to using precast

The connection is more unified so it is stronger

The weather is very influential when working

5) Development Phase

The alternative chosen from the previous stage is calculated, then the cost of the alternative design is compared with the initial design of the project.

Table 11: Comparison of the Price of Work Before and After Value Engineering

\begin{tabular}{llll}
\hline Work Item & $\begin{array}{l}\text { Price of Column Work Before } \\
\text { Value Engineering }\end{array}$ & $\begin{array}{l}\text { Price of Work After Value Engineer- } \\
\text { ing }\end{array}$ & Saving \\
\hline Column & $2.134 .027 .453,09$ & $1.936 .224 .161,69$ & $197.803 .291,41$ \\
Beam & 2.662 .631 .214 .84 & $2.551 .033 .625,43$ & 111.597 .589 .41 \\
\hline
\end{tabular}

6) Recommendation Phase

The alternative recommendation stages selected in the structural work items namely columns and beams in material use are as follows:

Table 12: Table Work Recommended Column Stage

\begin{tabular}{lll}
\hline Recomendation Phase & & \\
\hline Work Item: Column & Description & Cost \\
Type & K350 Reinforced Concrete & $2.134 .027 .453,09$ \\
Preliminary Design & K400 Reinforced Concrete & $1.936 .224 .161,69$ \\
Alternative Design & & $197.803 .291,41$ \\
Saving & $(9,27 \%)$ \\
\hline
\end{tabular}

Saving

Table 13: Beam Work Recommendation Stage Table

\begin{tabular}{lll}
\hline Recomendation Phase & & \\
\hline Work Item: Beam & Description & Cost \\
Type & K350 Reinforced Concrete & 2.662 .631 .214 .84 \\
Preliminary Design & K400 Reinforced Concrete & $2.551 .033 .625,43$ \\
Alternative Design & & 111.597 .589 .41 \\
Saving & & $(4,19 \%)$ \\
\hline
\end{tabular}

\subsection{Six sigma evaluation results}

In this research the application of the Six sigma method is the Integrated Teaching Laboratory \& Workshop. From the checklist conducted with the owner, there are several work findings that are not in accordance with the standardization of the project supplier. Along with the results of the defect set forth in the Non-Conferencing Report (NCR) table.

Defect per opportunities for structural work:

$$
\begin{aligned}
& \mathrm{DPU}=\frac{D}{\bar{V}} \\
& \mathrm{DPU}=\frac{D P U}{\theta} \\
& \mathrm{DPMO}=\mathrm{DPO} \times 1000000
\end{aligned}
$$

\begin{tabular}{lll} 
& Table 14: Non Conformance Report \\
\hline Given: & Total Defect from NCR & $: 39$ (D) \\
\hline Total Opportunities & $: 6(\mathrm{O})$ \\
Total Floor & $: 8(\mathrm{U})$ \\
Number of flooring units & $: 32$ unit $+(24$ unit lt. 9, 10) \\
\hline
\end{tabular}

DPU $=\frac{D}{\mathbb{V}}=\frac{a 9}{8}=4,875$ Defects per floor

$\mathrm{DPO}=\frac{\mathrm{DPU}}{\theta}=\frac{4975}{(9 x 6 x a 2)+24}=0,003125$ Defect per opportunity

$\mathrm{DPMO}=0,003125 \times 1.000 .000=3,125$

From the sigma data shown in the above table for defects generated by the structure of the work with a DPMO value of 3.125 is equivalent to 4.23 sigma with a yield of $99.69 \%$ following from the sigma table. 
Table 15: Table Relation Sigma and DPMO

\begin{tabular}{ll}
\hline SIGMA & PARTS PER MILLION \\
\hline 6 Sigma & 3,4 defect per million \\
5 Sigma & 233 defect per million \\
4 Sigma & 6.210 defect per million \\
3 Sigma & 66.807 defect per million \\
2 Sigma & 308.537 defect per million \\
1 Sigma & 690.000 defect per million \\
\hline
\end{tabular}

From the sigma value table above, it can be concluded that the construction of the Teaching Laboratory \& Workshop project has a defect value and has an impact on the pullback target of the completion of the project work, so in this study using the six sigma method for the work of the upper structure (columns, stairs, plates and beams) where stages of improving the quality of work by applying the DMAIC evaluation as follows:

1) Define

Define is the first step in the six sigma method, this stage is the stage to identify the product, the desire of the owner for the best results of each job, and the determination of the problems that exist in the construction of the Teaching Laboratory \& Workshop project where the process includes:

- The selection of work under study is the work of the upper structure in this case the work of columns, stairs, plates and beams.

- Identify according to the contract addendum that contains the project quality standardization

- Arranging project character projects which include: problems, objectives, benefits, limitations, assumptions, scope of project members and project plans.

- $\quad$ SIPOC table (Supplier, input, process, output and customer), each work and can be seen in the table (4.50 \& 4.51)

2) Measure

This measure stage is to measure the quality of each job, which refers to the CTQ (Critical to quality) to identify the results of the work. Pareto diagrams can answer the issue:

- Can find work that produces defects, which often occur in the project.

- Can find out the source of the cause of the defect.

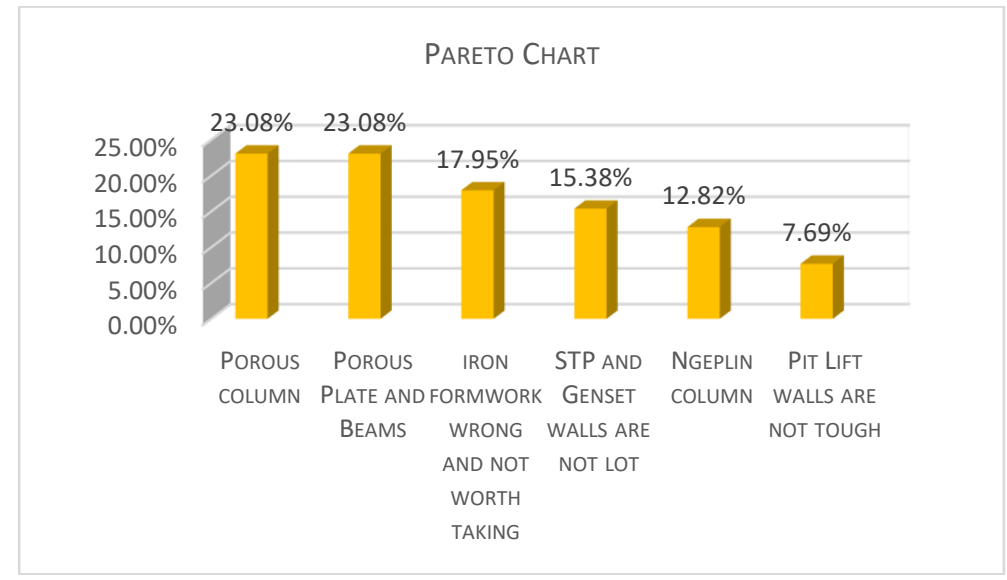

Fig. 6: Pareto chart.

From the picture above, the number of defects that most often occurs is the work of columns, plates and beams, then reinforcing and formwork and so on.

3) Analyze

Presentation in this analysis stage is to use fishbone diagrams or Ishikawa diagrams on each defect for easier understanding. To analyze the causes of defects using the fishbone diagram method or charts Ishikawa.

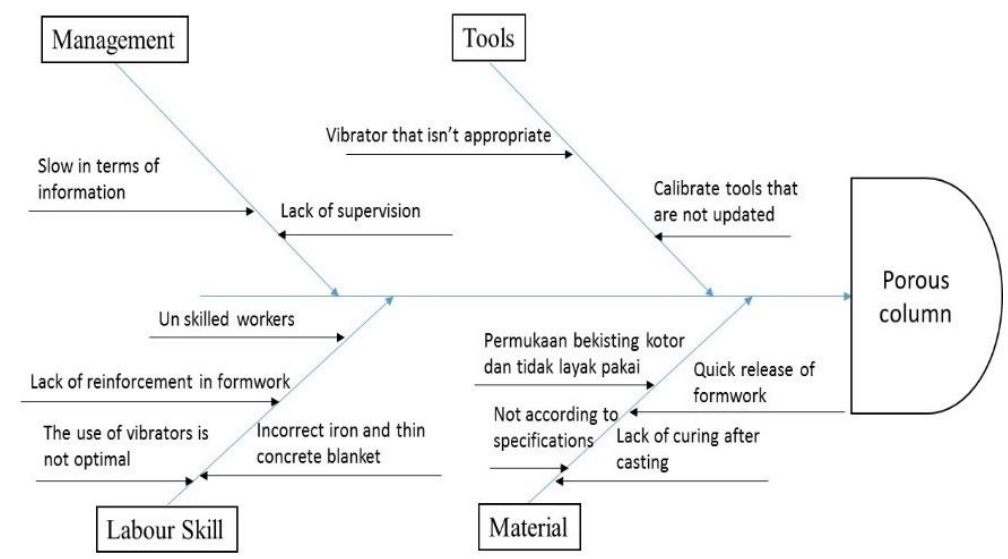

Fig. 7: Fishbone Diagram Column Work. 
Which can be seen that the defects produced in column work are caused by several factors, namely management problems in terms of information, worker skills caused by lack of supervision at work and workers' lack of expertise in working on the process column mounting/assembly. Then the material problems caused by the material used is not feasible and dirty, and the selection of material that is not in accordance with the specifications. And the problem of the equipment used is not suitable and the calibration is not updated.

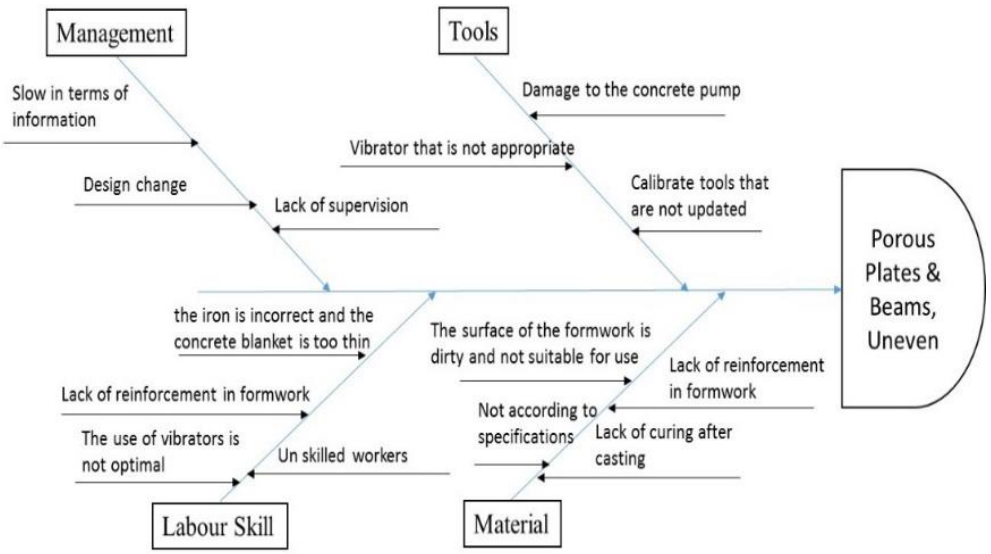

Fig. 8: Fishbone Diagram Plate \& Beam Work.

Which can be seen that in the defects produced in the work of plates and beams is caused by several factors, namely management problems caused by lack of supervision of the quality of the material and make changes to the design, the material used is not according to specifications, and lack of supervision in manpower / work processes. Then the equipment problem is the equipment not updated calibration, and the lack of equipment and does not match its function. And the problem of the skills of workers in doing similar work such as installation of improper reinforcement or not tight binding, and the use of vibrators is not optimal in the casting process.

4) Improve

A brainstorming will be provided, so that it is expected to be able to provide input to the project team, in order to improve the results better than the previous work, by doing PDCA (Plan Do, Check, Action). So that the defect in the work process can be reduced. The following are recommendations for reducing defects in the tables $(4.52, \& 4.53)$

5) Control

At the control stage will help the team to re-supervise the methods that have been applied in order to achieve the quality of work and can reduce the value of the work defect, so that more optimal to the repair work is checked as a control plan.

All title and author details must be in single-column format and must be centred.

\section{Conclusion}

From the results of Value Engineering can be applied to the work of the upper structure by going through 6 stages of value engineering (information, function analysis, sensitivity, evaluation, development and recommendations). By applying value engineering to the column and beam work there are savings of $9.27 \%$ and $3.19 \%$ of the initial design cost.

From the results of implementing Six Sigma, from the NCR value of 39, sigma data for defects produced by upper structure work with a DPMO value of 3.125 is equivalent to 4.23 sigma. And after that an evaluation using the DMAIC (Define, Measure, Analyze, Improve, and Control) process to reduce the defect of existing work / improve the process of work methods to (reduce the number of NCR) by increasing the sigma value parameter.

\section{Acknowledgement}

The author wants to express thanks for the support given by the PT Intraco Lestari (Building Integrated Teaching Laboratory \& Workshop FTUI project) and Mercu Buana University who provided insight and expertise that greatly assisted the research, especially because they have provided input, opinions, and information for this research.

\section{References}

[1] http://www.constructionplusasia.com/id/review-2018-dan-prediksi-pembangunan-konstruksi-2019/ (Accessed September 2019)

[2] DOE-USA. (2015). An Assessment of Energy Technologies and Research Opportunities. Chapter 5: Increasing Efficiency of Building Systems and Technologies, (September), 143-181. Retrieved from https://www.energy.gov/sites/prod/files/2017/03/f34/qtr-2015-chapter5.pdf

[3] Aziz, R. F., \& Hafez, S. M. (2013). Applying lean thinking in construction and performance improvement. Alexandria Engineering Jornal, 52 (4), 679-695. https://doi.org/10.1016/j.aej.2013.04.008.

[4] Olawale, Y., and S. M. (2010). Cost and Time Control of Construction Projects: Inhibiting Factors and Mitigating Measures in Practice. Yakubu Adisa Olawale, Ph.D., MCIOB and Ming Sun, Ph.D. (Professor). Construction Management and Economics, 28 (5) (2010), 509-526. https://doi.org/10.1080/01446191003674519.

[5] Bekr, G. A. (2015). Identifying Factors Leading to Cost Overrun in Construction Projects in Jordan. Journal of Construction Engineering, Technology and Management, 5(3), 25-33.

[6] Hameed Memon, A., Rahman, I. A., Abdullah, M. R., Asmi, A., \& Azis, A. (2014). Factors affecting construction cost performance in project management projects: Case of MARA large projects. International Journal of Civil Engineering and Built Environment, 1(1), $2289-6317$.

[7] Memon, A. H., Abdul Rahman, I., \& Abdul Aziz, A. A. (2012). The cause factors of large project's cost overrun: a survey in the southern part of Peninsular Malaysia. International Journal of Real Estate Studies (INTREST), 7(2), 1-15. Retrieved from http://eprints.uthm.edu.my/5007/1/2012_Study_of_causes_of_COR_in_large_projects_of_south_(INTRESTS)_-.pdf. https://doi.org/10.11591/ijaas.v1i1.537. 
[8] Forcada, N., Gangolells, M., Casals, M., \& Macarulla, M. (2017). Factors Affecting Rework Costs in Construction. Journal of Construction Engineering and Management, 143 (8). https://doi.org/10.1061/(ASCE)CO.1943-7862.0001324.

[9] Mahamid, I. (2020). Study of relationship between rework and labor productivity in Building Construction Projects. Revista de La Construcción, (1), 30-41. https://doi.org/10.7764/rdlc.19.1.30-41.

[10] Mahamid, I., \& Elbadawi, I. A. Q. (2014). Construction material waste: Recognition and analysis. Research Journal of Applied Sciences, Engineering and Technology, 8(11), 1312-1318. https://doi.org/10.19026/rjaset.8.1101.

[11] Jae-Seob Lee, 2018. Value Engineering for Defect Prevention on Building Façade. American Society of Civil Engineer.

[12] Berawi, M.A. (2014) Value Engineering Applications in the Building Construction Industry", University of Indonesia Publisher (UI-PRESS), Jakarta.

[13] Del, Younker. (2003). Value Engineering: Analysis and Methodology. https://doi.org/10.1201/9780203912751.

[14] SAVE, 2007. Value Standard and Body of Knowledge

[15] Prieto-avalos, M. C., Navarro-gonzález, C. R., González-angeles, A., \& Medina-león, S. V. (2014). Reduction waste by combining lean manufacturing and six sigma in an electronics industry. Research Journal of Applied Sciences, Engineering and Technology, 8(13), 1558-1562. https://doi.org/10.19026/rjaset.8.1133.

[16] Naslund Dag (2016). Lean Six Sigma - critical success factor revisited. International Journal of Quality and Service Sciences. Emerald Insight.

[17] Al Dairi, Jasim S.S., Khan M. Khurshid, Munive Hernandez, J. Eduardo. (2017) Knowledge-based Lean Six Sigma Maintenance system for Sustainable Building. International Journal of Lean Six Sigma. 8(1): 109-130. https://doi.org/10.1108/IJLSS-09-2015-0035.

[18] Husin, A.E, Detty, B (2018). The Integration of Aplication Line of Balance and Six Sigma Methods in Finishing Works at Hotel High Rise Building. International Journal of Scientific Research Engineering \& Technology. ISSN 2278-0882. 